\title{
Part Three, Book Two: The Rays, or the Eternal Way
}

\author{
Ephraim Meir
}

In Part III of the Star, which discusses redemption as the relationship between man and the world, Rosenzweig creates a parallel between Jews (III.1) and Christians (III.2) before concluding that God is the "truth" above them (III.3). The two communities take part in this truth, which is higher than the truth experienced by either of these communities separately. Rosenzweig used older material in order to write III.1 and III.2. He was less excited about writing these sections, but curious about the outcome of III.3, which speaks of God as the "truth".

Rosenzweig describes how each community lives redemption differently: the intimate Jewish community lives eternity now, while the Christian missionary community involves itself in history and strives for eternity. Rosenzweig bases his thinking on Judaism with Christianity as its "antipodic child" not by analysing their respective faiths, but by using a quasi-sociological description of both communities. He writes on the Jewish people and on Christian individuals. The introverted Jewish life, which is, so to speak, not of this world, constitutes the "fire" of the Star. The "rays" of the Star are Christianity, involved in the world and working in history in order to bring people to the Father through the mediation of the crucified.

In Rosenzweig's view, Christians are eternally on the way, whereas Jews are the eternal people. They are related in a critical-complementary relationship.

How to cite this book chapter:

Meir, E. 2021. Part Three, Book Two: The Rays, or the Eternal Way. In: Brasser, M., Bojanić, P. and Ciglia, F. P. (eds.) The Star for Beginners: Introductions to the Magnum Opus of Franz Rosenzweig. Pp. 159-165. London: Ubiquity Press. DOI: https://doi.org/10.5334/bco.m. License: CC-BY 
The relationship is unequal, because of the supremacy of Judaism over Christianity. Rosenzweig developed a rather positive attitude towards Christianity, but clearly favours Judaism. Jews anticipate the eschaton, whereas Christians strive to reach it by bringing the orientation of revelation in history. Judaism is rooted in itself, freed from time and history, whereas Christians work in the world and in history in order to vanquish paganism. Eternity is in the blood of the Jewish people, who transmit it from generation to generation. They have a land, a tongue and a law, all of which are eternal. The Jewish people are meta-historic, whereas other nations strive in vain for eternity in their respective States. Only the community of Christians represents an eternal way.

Throughout the Star, one finds philosophical reflections on politics and on aesthetics, both of which according to Rosenzweig represent a false striving for eternity. Also in III.2 it is clear that art and politics are not about real life. The plastic arts are mute and music is blind. Poetry is seen as the highest form of art, which is not surprising given Rosenzweig's predilection for language. In his philosophy of art, the applied arts of speech and gestures in liturgy receive special attention. In III.2 there is an ascending order of architecture, church music and dance. In III.2, he also develops a "messianic politics", in which he criticizes Hegel's problematic exaltation of the State and its inherent violence. In the midst of the collapse of the Kaiserreich, Rosenzweig becomes aware of eternity as a life outside the State and outside political life. Jews and Christians are associated with eternity; they are the "nevertheless" in the world against the world, beyond dominion and war.

As in I and II, Rosenzweig continues talking about the world (as in I.1), man (as in I.2) and God (as in I.3), as well as about creation (as in II.1), revelation (II.2) and redemption (II.3). III.1 and III.2 present old, known things, and Book Three (III.3) produces a thrill in him. III.1 on the Jewish people and III.2 on Christians are parallel responses to the revelation. III.3 is above them, like a lintel above doorposts.

At the start of Book Two, Rosenzweig brings Maimonides's characterization of Christianity as a "great error" ("große Irreleitung") and a "delusion" ("Wahn"). Christianity worships another beside God, but it paves the way for the Messiah to come. At the end of Book Two, in a kind of inclusion, he quotes Yehuda Halevi, who also gave a function to Christianity in the bringing of the Messiah. He uses Halevi's parable of the seed-kernel (Judaism) that falls in the earth: seemingly nothing remains of it, yet it becomes a big tree (Christianity and Islam) that brings forth the fruit (the Messiah) like the one out of which its seed once came. Maimonides's and Halevi's view on Christianity (not that on Islam) fit Rosenzweig's vision on Christianity as the "eternal path", complementary to Judaism as the "eternal way". Jews are the heart, the fire of the Star, Christians are the rays which shoot out. With this simile, Rosenzweig made it clear that the rays are nothing without the fire, whereas the fire needs to recognize the rays. 
Immediately after Maimonides's evaluation of Christianity, Rosenzweig reflects on the relationship of Christians to time. Whereas the "eternal people" creates its own time, being on the bridge over the river of time, Christianity as the "eternal way" leads through time. Christians take up the contest with the river, they view the river as the flow of time from the steel tracks and the river is for them only a sign that they are on their way. They come from a place and go to a place "beyond" the river and so, they get power over time. Christians live always in the present, since what is before Christ is the past, whereas the future is Christ's expected return and the last judgment.

Rosenzweig depicts eternal life and the eternal way as both eternal. Yet, in his geometrical thought, they are as different as the infinity of a point and of a line. The point in its infinity is never wiped away, it is self-preserved. The infinity of the line consists in its unlimited extension. In non-figurative language: Christianity must always spread further, it must be missionary, just as it is necessary for Judaism to seal itself off. Begetting (Erzeugen) in Judaism is bearing witness (Zeugnis) for eternity; in Christianity one bears witness in faith, which is faith in the way. The Christian faith is faith in something, while the Jew does not have faith in something, he himself incarnates faith; the Jewish faith is the product of begetting. Rosenzweig explains that, on the eternal way, individuals are united to mutual action in the world. Ecclesia is the assembly of individuals, who bear testimony to Christ. A bond of brotherliness "in the Lord" unites people beyond differences of sex, age, class and race.

In III.2 Rosenzweig points to many other differences between Jews and Christians. Whereas the Christian experiences his Christianity in the brother who stands nearest, the Jew lives eternity in the oldest and the youngest, in the grandfather who is blessing and the grandchild who receives the blessing. The Christian in his faith goes back to the first Christian, the Jew in hope looks forward to the last days, to the Davidic Messiah. The Jew is rooted in himself, the Christian looks for expansion and mission. Another great difference between the twin religions lies in the fact that Judaism is the one people and the eternal people that carries oppositions in itself, whereas the peoples of the world meet the oppositions where they are separated the one against the other.

Rosenzweig specifies how God, man and the world are conceived differently in both responses to the divine revelation. In the elucidation of the different views on God, man and the world, Rosenzweig develops a hierarchical thinking: he has a clear preference for the oneness in Judaism that contrasts with the duality in Christianity. The Christian way makes man, world and God into Christian man, Christian world and Christian God: the way of the Christian is through the world, along the river of time. In the Jewish view, God, man and the world are conceived differently.

For the Jew, God is just and loving, creator and revealer; divine love and divine justice go together. The Christian has a twofold approach to God. There is the Father and the Son: only through the Son, who is a man, does one dare to 
approach the Father. With God who became man in Christianity, Rosenzweig sees a piece of paganism. With this God who must be man, the Christian walks with trust through life, as a brother in the Lord. Yet, he also goes another way, the way with the Father in the sphere of truth. This twofold way to God is not existent in Judaism. Both God and man are approached differently in Judaism and Christianity. A Jew is human and Jewish, loving God and beloved by God, but these oppositions come together in one person. In the Christian, these oppositions or separated ways clash. The same is true for the approach to the world. For the Jew, the world is full of slippery transitions between this world and the future world, whereas the Christian lives the twofold order of State and Church.

Before analyzing the spiritual year of Christians as parallel to that of Jews, Rosenzweig brings his reflections on art and its relation to the community of faith. Whereas III.1 dealt with the Jewish yearly circle in which mutuality is lived, III.2 discusses the Christian yearly circle that prepares the individual soul for mutuality. It is in this perspective that art, more specifically applied art, plays an enormous role in Christianity. Rosenzweig compares art with an attentive woman who takes care of her household through daily services and gives her husband strength for the great hours of public life. Many buildings serve multiple purposes; the house of God, however, has only one aim: one lingers in it in order to stay in mutuality with others in one room. Architecture and painting are helpful in realizing this goal. The garment of the priest is strictly for worship. The activity of the priest can only take place with specific clothing. His garment, strictly for worship, hides his personality, but brings a beyond.

After these preparatory remarks, Rosenzweig proceeds to depict the Christian yearly cycle. In his analysis of the Jewish and Christian calendars, he was influenced heavily by Rosenstock's calendar thinking: time was linked to calendars. The word had a great role in the different liturgies. Whereas in Jewish liturgy, the word is a symbol of the already established mutuality, in Christian services the word takes the individual by the hand and leads him to mutuality. We meet here again Rosenzweig's basic idea that the Jewish collective is a fact and that Christians are individuals who are still on their way to the aim that Jews have already reached. Augustine and Luther made the word into a sacrament that prepares the individual. As in Judaism, Christianity has a holiday of mutual listening. Significantly, the seventh day became in Christianity the first day. For Christians as eternal beginners and people with eternal youth, Sunday is the day of spiritual refreshment, the beginning of the week. Jews on Sabbath commemorate the divine rest on the seventh day and the freedom from the house of slavery in Egypt.

Rosenzweig parallels the first Sunday of Advent somehow with the Day of Atonement. However, Yom Kippur celebrates redemption and does not fall as a rule on a Sabbath, although it has an increasingly Sabbath-like character. Also the first Sunday of Advent has increasing Sunday-like radiance and announces the beginning revelation. 
Like in Judaism, Christians have three holiday periods. Again Rosenzweig makes some remarks on art, this time on church music, inserted in the three festivals. Ecclesiastic music soars out of the artificial frame of "ideal time", just as ecclesiastical architecture and painting soar out of the artificial frame of "ideal space". In the Church application of music, music functions within the Christian chronology that is characterized by the central, epoch-making event of Christ's birth, with times before and after this event. It creates "real time". As architecture and painting, music prepares the individual soul onto the mutual way, it awakens each individual to the same feelings.

The sacrament of Holy Communion is distinguished from the Seder, from which it originates. Whereas the Seder is the festival of commemoration, Holy Communion belongs to the holiday of the way. In the Seder, mutual life becomes visible; in Holy Communion, each individual participates in the meal. The entire Seder is pervaded with hope for redemption, while Holy Communion is the sacrament of revelation.

The three Christian holiday periods start with Christmas at the beginning of the liturgical year. In Judaism, Pesach as the holiday of freedom of the people starts the liturgical year; in Christianity it is the birth of Christ, as the creation of revelation. Before Christmas, Advent brings the prophecies of the "Old" Covenant. After Christmas, the New Year and the holiday of the Three Kings bring secular life and faith together; redemption rings out. The Epiphany anticipates the future adoration of the divine child by all.

The Easter holidays are the real holidays of revelation. Parallel to the miracle at Sinai with the gift of the Torah after the Exodus (that has to be remembered), the Cross and not the manger are permanently before Christian eyes. The Christian greets the head full of blood and wounds: he is face to face with Christ. The entire holiday time, from fasting during Lent through Good Friday until the Pascha, prepares him for the central event in Christian life: the holiday of the revelation of redemption.

Pentecost, the third holiday, is dedicated to redemption. Just as Succot recalls the final rest only in the provisional one, Pentecost recalls the beginning of redemption. In Pentecost, the Church mastering all tongues acts in the world. Using a Jewish phraseology, Rosenzweig writes that God speaks everywhere with the words of man. However, Pentecost remains merely a first glance up to redemption. Rosenzweig notes that Christians do not have a special holiday of redemption, they do not have something similar to the Days of Awe. These days are lacking in the Christian calendar. Christmas celebrates the beginning, Yom Kippur the completion. In a sentence that encapsulates Rosenzweig's entire view on Christianity, he writes that in the Christian consciousness, the difference between revelation and redemption is blurred. The distinction between revelation and redemption is the eminently Jewish element in the Star.

Rosenzweig also pays attention to the commemorative holidays of Tisha be-Av, Purim and Hanukkah, which are extraneous to the Torah. These historical holidays became fixed, like the entire Jewish history. The historical 
memorial days of Christians are different: birthdays of kings or holidays for liberation last as long as the State lasts, they satisfy people as a sign of their permanence through their temporality and alteration.

The Church, Rosenzweig concludes, is a kind of mission to the pagans. It casts its transfiguring light upon nations, sowing eternity into the living. The Church participates in the life of the nations, but brings also its own history, for instance in the holiday of the reformation or the holidays of the saints.

Rosenzweig resumes his position towards Christianity again when writing on mutual kneeling. Mutual kneeling characterizes the Christian festivals: one kneels in front of the manger, in front of the Cross and before the transubstantiation in the Mass. Yet, only in Judaism, Rosenzweig maintains, the bending of every knee is celebrated in special holidays, the holidays of redemption. Only Jews with mutual kneeling live the eternity of redemption. Genuflection as the final redemption remains foreign to Christianity. Christians are on the way, they celebrate redemption in holidays of time.

At this point, Rosenzweig again discusses art, this time the art of poetry, but also gestures, dance and glance. As architecture and music, poetry had to leave its "ideal world" in favor of the "real world". Finally, poetry had to learn to be silent. Gestures, most of all kneeling, concern the whole man and are beyond action and speech. Again Rosenzweig jumps to the Jewish world in order to explain the importance of gestures. In the Jerusalem Temple, there was not even the smallest open place in the crowd that gathered in the forecourt, but when they fell face down, there was plenty of space.

Also outside the churches, in parades and processions and in plays such as Oberammergau, Christianity manifests itself. Rosenzweig discusses dance, collective dance, but also the dance of the individual, which is the first gesture. The simplest gesture is the glance: one may forget a word, but an eye that has glanced at us once, he writes, beholds us as long as we live. In his description of the Christian liturgy, Rosenzweig constantly returns to his basic scheme in which the Jews live eternal life, whereas Christians are the eternal way. Dance, for instance, is not performed in the Church, the procession goes out into the city. In Judaism, that celebrates redemption in the closed circle of the community, dance takes place on Simhat Torah, inside the house of God. And the Hasid dances, praising God "with all his bones". Christians are on their way: in the Christian mindset, baptism brings the individual on his way towards redemption. Of the five other sacraments that accompany a person through the events of his life and bring him towards redemption (the Eucharist being the sacrament of revelation), baptism is the central one.

Christianity, Rosenzweig repeats in conclusion, is young. The eternal people rests in the house of life; the nations remain on the way, and their way is the way of the Cross. The State with its incessant goals and war cry competes with Jewish life that has reached the goal. Art competes with the Christian way of the Cross. It is under the Cross that the Christian knows himself one with all souls. 
Instead of artistic concentration upon the own suffering, it is the incomparable suffering on the Cross that unites souls who, on their way, experience eternity.

In a somewhat problematic phrasing, Rosenzweig writes that the Christian focuses upon the blood that flows from the Cross; it runs from the Cross into his veins, but the blood does not circulate in his veins themselves. The Christian feels the refreshment of the circulation of the blood from the Cross running in his veins and from there, it flows downward in the ocean of history. Continuing his metaphoric language, Rosenzweig closes III.2 by returning to the Jewish people: only one single water on earth circles within itself, without inflow or outflow, not flowing into the sea. This wonder and scandal for others is the eternal people.

Though Rosenzweig greatly respected Christianity, his view as formulated in the Star starts with a certain superiority of Judaism in comparison with Christianity. In view of the attempt of his Christian friends to convert him, he considered his own Judaism as "the unutterable happiness of being a Jew". He saw Christianity as an important lifestyle next to the Jewish one and noted many parallels and differences between the two ways of life. Jews had a special function towards Christians, which consists in reminding Christians that they must not revert again to their previous pagan stage. Christianity illuminates the entire world; Jews with their unity between nation and religion remind the Christians that they are on their way. The synagogue looks prophetically into the future. The Church also wants eternity, and yet Christians are much more linked to history. They have the task of bringing pagans in history to the one God and to vanquish their own paganism. Rosenzweig could not conceive of his own self as separate from the image of the other. He strove for a critical complementary relationship: Christians need Jews as their source, and Jews need Christians as the "rays" of their "fire".

\section{Further readings}

Bowler, M. G., (1997), The Reconciliation of Church and Synagogue in Franz Rosenzweig, Ann Arbor Mich.

Dober, H. M., (1990), Die Zeit ernst nehmen. Studien zu Franz Rosenzweigs «Der Stern der Erlösung», Würzburg, Königshausen \& Neumann.

Surall, F., (2003), Juden und Christen - Toleranz in neuer Perspektive: Der Denkweg Franz Rosenzweigs in seinen Bezügen zu Lessing, Harnack, Baeck und Rosenstock-Huessy, Gütersloh, Chr. Kaiser Gütersloher Verlagshaus. 